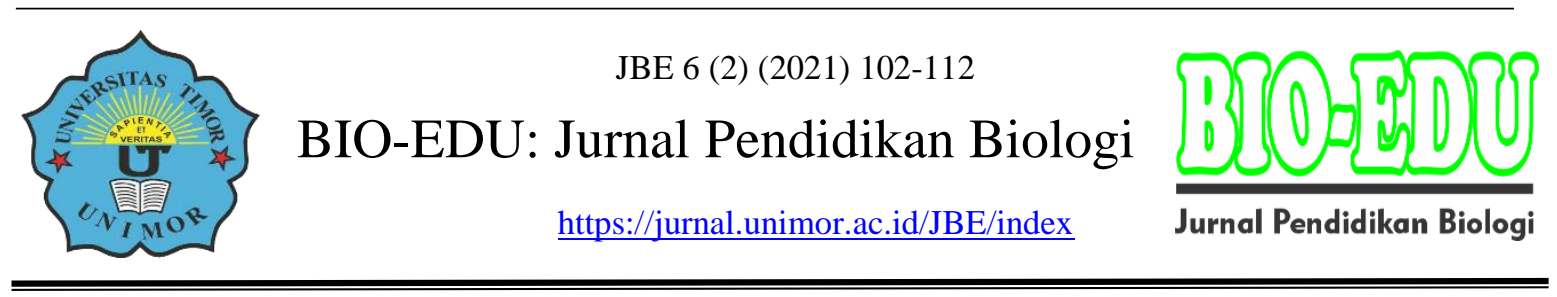

\title{
Studi Kunjungan Harian Arthropoda pada Tanaman Ageratum conyzoides dan Acalipa australis di Area Pertanian Dusun Ketanon Kecamatan Diwek sebagai Bahan Pengembangan E-Katalog Arthropoda
}

\author{
Anggun Wulandari ${ }^{1}$, Maisy Kamilah ${ }^{2}$ \\ ${ }^{1,2}$ Universitas KH. A. Wahab Hasbullah J1. Garuda, No. 09 Tambakberas Jombang \\ Email: anggun.4w@gmail.com
}

DOI: https://doi.org./10.32938/jbe.v6i2.1187

\begin{abstract}
Abstrak
Kunjungan harian Arthropoda dapat ditentukan dari frekuensi dan distribusi temporal Arthropoda pada setiap waktu pengamatan dalam mengunjungi tanaman Ageratum conyzoides dan Acalipa australis. Penelitian ini bertujuan menganalisis jenis, frekuensi, dan distribusi temporal serta bahan pengembangan e-katalog dari kunjungan Arthropoda pada tanaman Ageratum conyzoides dan Acalipa australis di area pertanian dusun Ketanon kecamatan Diwek. Metode pengambilan data dengan menggunakan metode "visual control" yang dikembangkan oleh Frei dan Manhart (1992) yang telah dimodifikasi. Penelitian dilakukan di area pertanian dusun Ketanon kecamatan Diwek dengan pengambilan data dilakukan pada pukul 06.00-07.00, 11.00-12.00, dan 16.00-17.00 sebanyak 3 kali ulangan pada masing-masing tanaman. Hasil penelitian menunjukkan jenis Arthropoda berjumlah 11 famili dengan 12 macam spesies. Frekuensi kunjungan harian Arthropoda tertinggi pada tanaman Ageratum conyzoides adalah famili Agromyzidae (hama) dengan kunjungan rata-rata 4,22 individu/jam, sedangkan pada tanaman Acalipa australis adalah famili Formicidae (musuh alami) dengan kunjungan rata-rata 2,88 individu/jam. Distribusi temporal menunjukkan bahwa waktu kunjungan Arthropoda setiap individu/jam adalah berbeda disetiap kegiatan/kebutuhan berkunjung masing-masing hewan Arthropoda. Serta bahan pengembangan e-katalog diperoleh dari hasil data pengamatan yang disusun dalam bentuk bahan pengembangan e-katalog yang sederhana.
\end{abstract}

Kata Kunci: Ageratum conyzoides; Acalipa australis; Arthropoda; E-katalog; Kunjungan Harian;

\begin{abstract}
Arthropoda daily visits can be determined from the frequency and temporal distribution of Arthropods at each observation time in visiting Ageratum conyzoides and Acalipa australis plants. This study aims to analyze the type, frequency, temporal distribution, and development of e-catalog materials from Arthropoda visits to Ageratum conyzoides and Acalipa australis plants in the agricultural area of Ketanon hamlet, Diwek district. The method of data collection using the "visual control" method developed by Frei and Manhart (1992) has been modified. The study was conducted in the agricultural area of Ketanon hamlet, Diwek district with data collection carried out at 06.00-07.00, 11.00-12.00, and 16.00-17.00 with 3 replications on each plant. The results showed that there were 11 types of Arthropods in 12 families with 12 species. The highest frequency of daily visits for Arthropods in Ageratum conyzoides was the family Agromyzidae (pests) with an average visit of 4.22 individuals/hour, while for Acalipa australis was the family Formicidae (natural enemies) with an average visit of 2.88 individuals/hour. . The temporal distribution shows that the Arthropoda visit time of each individual/hour is different in each activity/visiting need of each Arthropod animal. As well as e-catalog development materials obtained from the results of observational data compiled in the form of simple e-catalog development materials.
\end{abstract}

Keywords: Ageratum conyzoides; Acalipa australis; Arthropods; E-katalog; daily visits. 


\section{PENDAHULUAN}

Pengendalian hayati pada hama dapat dilakukan dengan melestarikan musuh alami yang meliputi predator (pemangsa), parasitoid, dan pathogen hama. Jenis-jenis predator, parasitoid dan hama tersebut tergabung dalam filum Arthropoda (Turista, 2011). Keberadaan Arthropoda dapat menguntungkan petani dalam penyeimbangan ekosistem sehingga penting untuk dijaga dengan cara pengurangan penggunaan pestisida pada tanaman pertanian yang salah satunya dapat dilakukan dengan menjaga atau melindungi populasi Arthropoda di area pertanian.

Arthropoda melakukan kunjungan karena dapat dipengaruhi oleh adanya tumbuhan liar pada area pertanian dengan distribusi temporal yang berbeda, irama pada serangga disebut jam biologis (Purwanti, 2011). Jam biologis merupakan waktu yang mengatur aktivitas Arthropoda untuk istirahat dan beraktivitas, sehingga adanya irama pada serangga dapat mempengaruhi kunjungan harian Arthropoda pada pagi, siang dan sore hari. Kunjungan harian Arthropoda dapat mempengaruhi pengelolaan habitat dengan bantuan peran tumbuhan liar di area pertanian sebagai refugia.

Refugia adalah mikrohabitat yang menyediakan tempat berlindung secara spasial dan/atau temporal bagi musuh alami hama, seperti predator dan parasitoid, serta mendukung komponen interaksi biotik pada ekosistem, seperti polinator atau serangga penyerbuk (Keppel dkk., 2012). Keberagaman musuh alami karena adanya tanaman refugia akan menghasilkan terbentuknya ekosistem yang lebih stabil dan dapat digunakan sebagai mikrohabitat sebagai penarik kunjungan musuh alami sehingga berpotensi dalam meningkatkan hasil produksi panen khususnya di area pertanian dusun Ketanon kecamatan Diwek.

Pemilihan dua jenis tanaman refugia yaitu Ageratum conyzoides dan Acalipa australis karena kedua tanaman tersebut dapat menarik kunjungan Arthropoda di pinggiran area pertanian tebu yang telah ditanam di Dusun Ketanon Kecamatan Diwek agar dapat diketahui jenis Arthropoda yang menguntungkan atau bahkan merugikan bagi para petani. Hasil studi kunjungan harian arthropoda pada tanaman refugia ini akan dijadikan sebagai bahan pengembangan bahan ajar Arthropoda yang berupa e-katalog.

E-katalog disebut juga dengan media teknologi berbasis online yang berguna sebagai alat bantu peraga materi pelajaran dalam proses pembelajaran yang penggunaanya serupa dengan media katalog. Media katalog masuk dalam kategori media secara tepat dapat mengatasi kesulitan belajar akibat adanya perbedaan sifat gambar mati atau gambar diam (still picture) (Handayani, 2018), sehingga penelitian tentang kunjungan harian Arthropoda pada tanaman Ageratum conyzoides dan Acalipa australis di area pertanian Dusun Ketanon Kecamatan Diwek penting dilakukan, yang mana hasilnya akan dijadikan sebagai bahan dasar pengembangan e-katalog Arthropoda yang berguna untuk memudahkan pendidik dalam penyampaian materi pembelajaran Arthropoda.

\section{METODE}

Penelitian ini merupakan penelitian deskriptif eksploratif dengan menggunakan metode pengamatan "visual control" yang dikembangkan oleh Frei dan Manhart (1992) yang telah dimodifikasi. Metode ini merupakan metode pengamatan jarak jauh dengan mengamati secara langsung arthropoda yang mengunjungi tanaman refugia pada jarak pengamatan 2 meter dengan melakukan pada satu titik yang telah dijadikan tempat pencuplikan. Pengambilan data dilakukan pada pukul 06.00-07.00, 11.00-12.00, dan 16.00-17.00 di setiap ulangan pada dua jenis tanaman refugia yaitu Ageratum 
conyzoides dan Acalipa australis yang masing-masing jenis tanaman dilakukan pengamatan sebanyak 3 kali ulangan.

Penelitian ini terdapat 3 variabel antara lain: variabel bebas yaitu tanaman Ageratum conyzoides dan Acalipa australis, variabel terikat yaitu jenis hewan Arthropoda pada tingkat famili, dan variabel kontrol yaitu area pertanian dusun Ketanon kecamatan Diwek. Subjek penelitian ini yaitu semua Arthropoda teramati yang mengunjungi tanaman Ageratum conyzoides dan Acalipa australis di area pertanian dusun Ketanon kecamatan Diwek. Data yang diperoleh untuk jenis arthropoda ditabulasikan dalam tabel, frekuensi kunjungan harian menggunakan statistik inferensial dengan parametrik uji t berpasangan (pair-sample $t$ test), distribusi temporal dilakukan analisis deskriptif dengan menghitung rata-rata frekuensi tiap waktu pengamatan (jam), dan bahan pengembangan e-katalog di desain dengan mengacu pada jenis arthropoda yang ditemukan berkunjung pada tanaman Ageratum conyzoides dan Acalipa australis dan di deskripsikan secara ringkas.

\section{HASIL DAN PEMBAHASAN}

Hasil pengamatan kunjungan harian Artropoda pada tanaman Ageratum conyzoides dan Acalipa australis di area pertanian dusun Ketanon kecamatan Diwek ditemukan sebanyak 7 famili dengan 7 spesies pada tanaman Ageratum conyzoides (Tabel 1) yang meliputi 4 spesies berperan sebagai musuh alami dan 3 spesies berperan sebagai hama. Sedangkan, pada tanaman Acalipa australis ditemukan kunjungan Arthropoda sebanyak 7 famili dengan 8 spesies (Tabel 2) yang meliputi 5 spesies berperan sebagai musuh alami dan 3 spesies berperan sebagai hama.

Tabel 1. Jenis Arthropoda yang Ditemukan pada Tanaman Ageratum conyzoides

\begin{tabular}{lccccc}
\hline No & Ordo & Famili & Nama & Gambar & Peran \\
\hline 1. & Araneae & Oxyopidae & Laba-laba & Musuh alami \\
\hline 2. & Hymenoptera & Sphecidae & Lebah & Musuh alami \\
\hline 3. & Diptera & Dolichopodidae & Lalat hijau & Musuh alami \\
\hline 4. & Diptera & Agromyzidae & $\begin{array}{c}\text { Lalat } \\
\text { penggorok }\end{array}$ & Hama \\
\hline 5. & Diptera & Muscidae & $\begin{array}{c}\text { Lalat } \\
\text { rumah }\end{array}$ & Musuh alami \\
\hline 6. & Lepidoptera & Lycaenidae & Kupu-kupu & Hama \\
\hline 7. & Hemiptera & Cicadellidae & Wereng & Hama \\
\hline
\end{tabular}


Tabel 2. Jenis Arthropoda yang Ditemukan pada Tanaman Acalipa australis

\begin{tabular}{|c|c|c|c|c|c|}
\hline No & Ordo & Famili & Nama & Gambar & Peran \\
\hline 1. & Diptera & Agromyzidae & $\begin{array}{c}\text { Lalat } \\
\text { penggorok }\end{array}$ & & Hama \\
\hline 2. & Diptera & Muscidae & $\begin{array}{l}\text { Lalat } \\
\text { rumah }\end{array}$ & & Musuh alami \\
\hline 3. & Hemiptera & Cicadellidae & Wereng & & Hama \\
\hline 4. & Hymenoptera & Formicidae & $\begin{array}{l}\text { Semut } \\
\text { kebun }\end{array}$ & & Musuh alami \\
\hline 5. & Hymenoptera & Formicidae & Semut api & & Musuh alami \\
\hline 6. & Diptera & Ephydridae & Lalat alkali & & Musuh alami \\
\hline 7. & Araneae & Salticidae & $\begin{array}{l}\text { Laba-laba } \\
\text { pelompat }\end{array}$ & & Musuh alami \\
\hline 8. & Trombidiformes & Tetranychidae & $\begin{array}{l}\text { Tungau } \\
\text { laba-laba }\end{array}$ & & Hama \\
\hline
\end{tabular}

Jenis Arthropoda yang berkunjung pada tanaman Ageratum conyzoides yang terdapat 4 jenis Arthropoda sebagai musuh alami (Oxyopidae: laba-laba, Sphecidae: lebah, Dolichopodidae: lalat hijau, Muscidae: lalat rumah) dan 3 jenis Arthropoda sebagai hama (Agromyzidae: lalat penggorok daun, Lycaenidae: kupu-kupu, Cicadellidae: wereng). Pada tanaman Acalipa australis terdapat 5 jenis Arthropoda sebagai musuh alami (Muscidae: lalat rumah, Formicidae: semut kebun \& semut api, Ephydridae: lalat alkali, dan Salticidae: laba-laba pelompat) dan 3 jenis Arthropoda sebagai hama (Agromyzidae: lalat penggorok daun, Cicadellidae: wereng, dan Tetranychidae: tungau laba-laba).

Hasil jenis Artropoda yang berkunjung pada kedua tanaman tersebut menunjukkan bahwa famili yang berkedudukan sebagai musuh alami lebih banyak jenisnya dibandingkan hama. Hal ini sesuai dengan Tauruslina et.al (2015) dalam Sumarmiyati (2019) menyebutkan bahwa "habitat ekosistem sawah diduga turut mempengaruhi keberadaan serangga pada ekosistem tersebut". Untung (2006) dalam Sumarmiyati (2019) juga menjelaskan bahwa "jika terjadi peningkatan populasi serangga hama maka akan diikuti oleh peningkatan populasi musuh alami (respon numerik) dan respon fungsional yaitu peningkatan daya makan atau daya parasitasinya". 
Data frekuensi Arthropoda yang ditemukan berkunjung pada tanaman Ageratum conyzoides dan Acalipa australis selama 3 kali ulangan dianalisis menggunakan uji t berpasangan (pair-sample t test) dan dihasilkan rerata seperti pada Tabel 3.

\section{Tabel 3. Rerata Frekuensi Kunjungan Harian Arthropoda pada Tanaman Ageratum conyzoides dan Acalipa australis}

\begin{tabular}{ccc}
\hline \multirow{2}{*}{ Famili } & \multicolumn{2}{c}{ Rerata Frekuensi Kunjungan Harian Arthropoda } \\
\cline { 2 - 3 } & Ageratum conyzoides & Acalipa australis \\
\hline Oxyopidae & 0,55 individu/jam & $0,00 \mathrm{individu} / \mathrm{jam}$ \\
Sphecidae & $0,11 \mathrm{individu/jam}$ & $0,00 \mathrm{individu} / \mathrm{jam}$ \\
Dolichopodidae & $3,44 \mathrm{individu} / \mathrm{jam}$ & $0,00 \mathrm{individu} / \mathrm{jam}$ \\
Agromyzidae & $4,22 \mathrm{individu} / \mathrm{jam}$ & $2,11 \mathrm{individu} / \mathrm{jam}$ \\
Muscidae & $0,22 \mathrm{individu} / \mathrm{jam}$ & $1,55 \mathrm{individu} / \mathrm{jam}$ \\
Lycaenidae & $0,11 \mathrm{individu} / \mathrm{jam}$ & $0,00 \mathrm{individu} / \mathrm{jam}$ \\
Cicadellidae & $0,33 \mathrm{individu} / \mathrm{jam}$ & $0,44 \mathrm{individu} / \mathrm{jam}$ \\
Formicidae & $0,00 \mathrm{individu} / \mathrm{jam}$ & $2,88 \mathrm{individu} / \mathrm{jam}$ \\
Ephydridae & $0,00 \mathrm{individu} / \mathrm{jam}$ & $0,33 \mathrm{individu} / \mathrm{jam}$ \\
Salticidae & $0,00 \mathrm{individu} / \mathrm{jam}$ & $0,22 \mathrm{individu} / \mathrm{jam}$ \\
Tetranychidae & $0,00 \mathrm{individu/jam}$ & $0,33 \mathrm{individu} / \mathrm{jam}$ \\
\hline
\end{tabular}

Pada tanaman Ageratum conyzoides ditemukan sebanyak 7 famili (Oxyopidae, Sphecidae, Dolichopodidae, Agromyzidae, Muscidae, Lycaenidae, dan Cicadellidae) sedangkan pada tanaman Acalipa australis juga ditemukan sebanyak 7 famili (Agromyzidae, Muscidae, Cicadellidae, Formicidae, Ephydridae, Salticidae dan Tetranychidae), untuk famili Formicidae terdiri dari dua macam spesies yaitu semut kebun dan semut api. Hasil rerata frekuensi Arthropoda tertinggi pada tanaman Ageratum conyzoides adalah famili Agromyzidae sebesar 4,22 individu/jam, sedangkan pada tanaman Acalipa australis adalah famili Formicidae sebesar 2,88 individu/jam.

Hasil analisis uji t berpasangan pada kedua jenis tanaman Ageratum conyzoides dan Acalipa australis terdapat perbedaan yang signifikan pada rata-rata frekuensi kunjungan pada beberapa arthropoda, diantaranya yaitu untuk famili Oxyopidae (signifikan pada 0,013) dan Dolichopodidae (signifikan pada 0,043), dimana pada tanaman Ageratum conyzoides memiliki frekuensi kunjungan harian lebih tinggi dibandingkan dengan tanaman Acalipa australis, sedangkan famili Formicidae memiliki nilai yang signifikan yaitu 0,004 dimana pada tanaman Acalipa australis memiliki frekuensi yang lebih tinggi dibandingkan dengan tanaman Ageratum conyzoides. Pada famili yang lainnya yaitu famili Sphecidae (tidak signifikan yaitu 0,347), famili Agromyzidae (tidak signifikan yaitu 0,060), famili Muscidae (tidak signifikan yaitu 0,426), famili Lycaenidae (tidak signifikan yaitu 0,347), famili Cicadellidae (tidak signifikan yaitu 0,799), famili Ephydridae (tidak signifikan yaitu 0,195), famili Salticidae (tidak signifikan yaitu 0,169) dan famili Tetranychidae juga tidak signifikan yaitu 0,081 sehingga menunjukkan tidak terdapat perbedaan yang nyata antara kunjungan pada tanaman Ageratum conyzoides dan Acalipa australis.

Hasil penelitian menunjukkan bahwa selain frekuensi yang berbeda, ternyata arthropoda juga memiliki distribusi temporal yang bervariasi. Hasil distribusi temporal kunjungan harian Arthropoda pada masing-masing tanaman menunjukkan bahwa waktu 
kunjungan Arthropoda setiap individu/jam adalah berbeda, dengan kata lain setiap individu mempunyai waktu kegiatan/kebutuhan berkunjung masing-masing, hal ini sesuai dengan Wulandari (2016) bahwa "serangga memiliki aktivitas harian yang mengikuti biological clock yang menunjukkan aktivitas organisme pada waktu-waktu dan zona tertentu". Logan dkk (2006) menjelaskan bahwa laju perkembangan artropoda serangga sangat dipengaruhi oleh suhu, dan efek fenologis yang bergantung pada suhu ini ditambah dengan pergeseran dalam periode aktivitas harian untuk mangsa dan pemangsa, sehingga meningkatkan atau menurunkan peluang interaksi. Gambar sebaran distribusi temporal arthropoda yang berkunjung pada tanaman Ageratum conyzoides dan Acalipa australis dapat dilihat pada Gambar 1 dan Gambar 2.

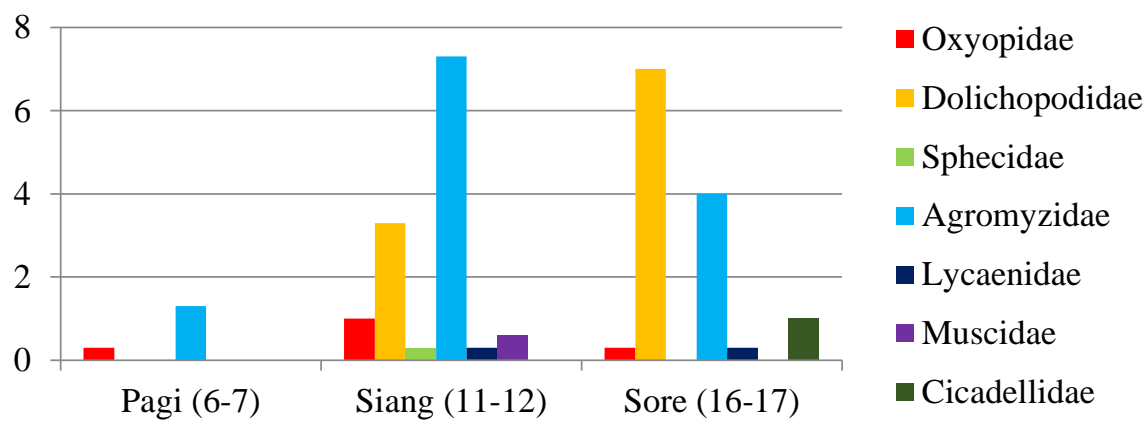

Gambar 1. Distribusi Temporal Arthropoda pada Tanaman Ageratum conyzoides

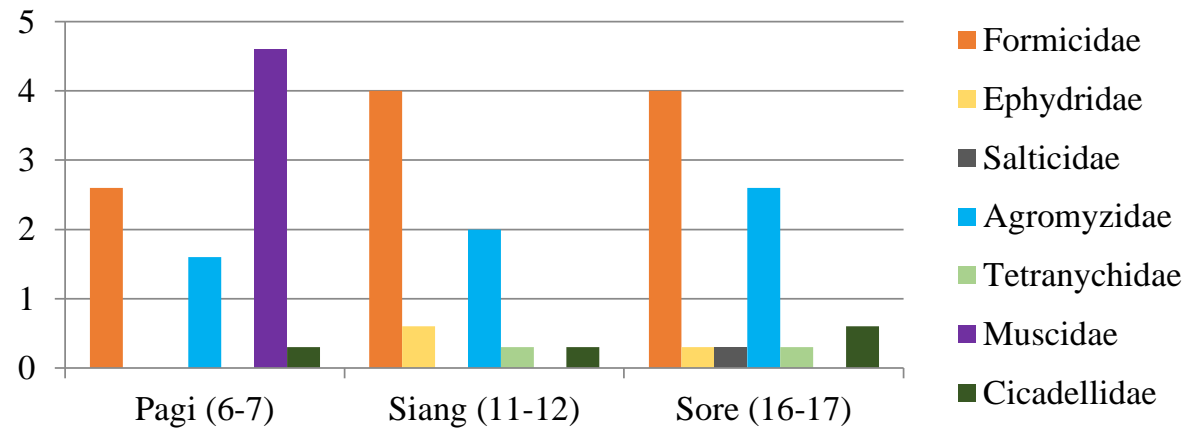

Gambar 2. Distribusi Temporal Arthropoda pada Tanaman Acalipa australis

Famili Oxyopidae (laba-laba) yang berperan sebagai musuh alami (predator) hanya ditemukan pada tanaman Ageratum conyzoides dengan distribusi temporal yang tidak menentu di pagi, siang, dan sore, hal tersebut menunjukkan bahwa Oxyopidae aktif sepanjang hari dan sesuai dengan pernyataan Anonimous (2002) dalam Wulandari (2016) yang menyatakan bahwa "laba-laba ini tergolong laba-laba pemburu, aktif sepanjang hari". Famili Dolichopodidae (lalat hijau) yang berperan sebagai musuh alami (predator) cenderung aktif pada siang dan sore hari, hal tersebut sesuai dengan pernyataan Anonimous (2002) dalam Wulandari (2016) bahwa "lalat ini dapat ditemukan di kebun teh dan senang sekali hinggap di atas daun di bawah cahaya matahari”. Lalat ini adalah makhluk siang hari (Wulandari, 2016). Oleh karena itu, famili Dolichopodidae selama pengamatan 3 kali ulangan, lalat hijau berkunjung setiap hari hinggap di daun, terutama pada siang dan sore hari, dan tidak pernah muncul di pagi hari.

Famili Sphecidae (lebah) memiliki memiliki distribusi temporal yang tidak menentu dikarenakan selama 3 kali ulangan Sphecidae hanya ditemukan di ulangan pertama pada kisaran jam 11.00-12.00, hal tersebut kemungkinan dikarenakan 
Sphecidae hanya berperan sebagai musuh alami (polinator). Sesuai dengan pernyataan Lumowa (2011) bahwa "Polinator umumnya mengunjungi tanaman berbunga dengan tujuan untuk mencari makan dalam hal ini bunga yang sedang mekar (anthesis), dimana mengandung zat gula (nektar) yang merupakan sumber makanan bagi polinator".

Famili Agromyzidae (lalat penggorok daun) berperan sebagai hama dan memiliki distribusi temporal yang cenderung aktif pada pagi, siang dan sore hari pada tanaman Ageratum conyzoides. Hal tersebut menunjukkan bahwa Agromyzidae aktif sepanjang hari sebagai bentuk pola penyerangan pada daun tanaman dan sesuai dengan pernyataan Zaironi (2015) bahwa "lalat ini menyerang daun tanaman dengan cara meletakkan telur di bagian epidermis daun". Sedangkan, Agromyzidae pada tanaman Acalipa australis memiliki distribusi temporal yang cenderung aktif di siang dan sore hari. Jadi, perbedaan frekuensi kunjungan arthropoda tersebut sesuai dengan pernyataan Turista (2011) yaitu "setiap famili memiliki kunjungan tertinggi yang berbeda pada tumbuhan yang berbeda. Akan tetapi pada pagi hari selama 2 kali ulangan pertama tidak ditemukannya lalat penggorok daun yang berkunjung dan ketika pagi hari di ulangan ketiga lalat tersebut meningkat dari jumlah kunjungan biasanya dengan jumlah 5 ekor, kemungkinan karena adanya faktor cerahnya cahaya di pagi hari, karena selama 2 kali ulangan pertama cuacanya berkabut dan udaranya dingin. Hal tersebut sesuai dengan Odum (1993) dalam Turista (2011) menyatakan bahwa "serangga memiliki kisaran suhu tertentu dimana ia dapat hidup".

Famili Muscidae (lalat rumahan) berperan sebagai musuh alami (parasitoid). Kunjungan Muscidae tidak menentu dikarenakan hanya berkunjung 2 kali waktu dalam 3 kali ulangan, yaitu pada siang hari di tanaman Ageratum conyzoides, sedangkan di tanaman Acalipa australis hanya berkunjung pada ulangan ketiga di pagi hari. Kunjungan Muscidae di tanaman Ageratum conyzoides kemungkinan dikarenakan cuacanya yang tidak stabil, antara tidak terlalu panas dan mendung yang bergantian serta dibarengi dengan angin. Sedangkan, di tanaman Acalipa australis dengan cuaca cerah pagi hari. Pernyataan tersebut sesuai dengan Alrazik dkk (2017) bahwa pada umumnya siklus hidup dan pola hidup lalat rumah ini (Musca domestica) sama dengan siklus dan pola hidup lalat pada umumnya, yakni memerlukan suhu $30^{\circ} \mathrm{C}$ untuk hidup dan kelembaban yang tinggi, tertarik pada warna terang sesuai dengan sifat fototrofiknya.

Famili Lycaenidae (kupu-kupu) berperan sebagai hama dan memiliki distribusi temporal hanya pada sore hari di ulangan pertama, kemungkinan hal tersebut dikarekan cuaca di sore hari yang selain ada kelembaban juga ada cahaya meskipun tidak panas. Hal tersebut sesuai dengan Alrazik (2017) bahwa "kelembaban udara dan intensitas cahaya merupakan dua faktor lingkungan yang juga mempengaruhi aktivitas kupu-kupu dalam mencari makanan". Oleh karena itu, frekuensi Lycaenidae sedikit dikarenakan intensitas cahaya yang kurang dan kemungkinan hanya faktor migrasi Lycaenidae.

Famili Cicadellidae (wereng) berperan sebagai hama. Cicadellidae pada tanaman Ageratum conyzoides hanya berkunjung pada sore hari di ulangan ketiga, kemungkinan Cicadellidae menyukai suhu yang rendah karena pada saat itu cuacanya sedang mendung dan sempat hujan sekejap. Hal ini sesuai dengan pendapat Khalshoven (1981) dalam Wulandari (2016) bahwa "umumnya Empoasca mampu hidup pada suhu $20^{\circ} \mathrm{C}-$ $23^{\circ} \mathrm{C}$ ". Sedangkan Cicadellidae di tanaman Acalipa australis memiliki distribusi temporal yang tidak menentu, sehingga menunjukkan bahwa Cicadellidae aktif sepanjang hari selama suhunya rendah yang dapat mendukung untuk bertahan hidup. Selaras juga dengan pernyataan Widayat (2007) dalam Indriati (2015) bahwa 
"umumnya Empoasca sp. menyerang pucuk/daun muda tanaman teh pada saat matahari tidak terik dan populasi tertinggi terjadi di akhir musim kemarau".

Famili Formicidae (semut hitam dan semut api) berperan sebagai musuh alami (predator). Formicidae memiliki distribusi temporal yang tidak menentu sehingga menunjukkan aktif sepanjang hari, karena di waktu pagi, siang dan sore Formicidae selalu berkunjung. Pernyataan tersebut sesuai dengan Wulandari (2016) bahwa "famili Formicidae pada tumbuhan liar Borreria repens DC. dan Setaria sp. menunjukkan keaktifannya sepanjang hari”. Akan tetapi pada suatu sore di ulangan kedua Formicidae tidak kelihatan berkunjung, kemungkinan dikarenakan cuaca sedang mendung dan angin lebat, hal tersebut sesuai dengan Raimundo dkk (2009) yang menjelaskan bahwa koloni semut menunjukkan aktivitas nokturnal sepanjang tahun, dan mereka mencari makan secara signifikan lebih intensif di musim hujan/hangat daripada di musim dingin/kering. Holldobler dan Wilson (1990) dalam Belchior dkk (2012) juga menjelaskan bahwa berbeda dengan lingkungan beriklim dingin atau gersang yang kondisi iklim ekstremnya membatasi aktivitas semut. Aktivitas semut yang suka bermigrasi juga mempengaruhi keaktifan kunjungannya, hal tersebut sesuai dengan pernyataan Turista (2011) bahwa "naik turunnya kunjungan Formicidae tiap waktu dipengaruhi oleh migrasi”.

Famili Ephydridae (lalat alkali) berperan sebagai musuh alami (parasitoid). Distribusi temporal hanya pada siang (ulangan kedua) dan sore (ulangan pertama) hari yang merupakan cuaca saat itu sedang panas bercampur mendung. Hal tersebut kemungkinan dikarenakan faktor migrasi Ephydridae dalam mencari makanan. Famili Salticidae (laba-laba pelompat) yang berperan sebagai musuh alami (predator) memiliki distribusi temporal yang tidak menentu karena hanya berkunjung di sore hari pada ulangan kedua dan famili Tetranychidae (tungau laba-laba) yang berperan sebagai hama memiliki distribusi temporal yang tidak menentu juga dikarenakan berkunjung hanya diulangan ketiga pada siang dan sore hari. Hal tesebut kemungkinan dikarenakan cuaca pada saat itu adalah sedang mendung dan angin lebat serta dapat juga dikarenakan oleh faktor migrasi Salticidae dan Tetranychidae dalam mencari makanannya.

Keanekaragaman serangga dipengaruhi oleh keanekaragaman parasitoid dan predator sehingga serangga lain sebagai inang bagi parasitoid dan mangsa bagi predator yang dapat mempengaruhi bahwa semakin tinggi keanekaragaman parasitoid dan predator maka semakin tinggi juga keanekaragaman serangga lain di suatu habitat tersebut (Pebrianti, 2016). Melalui peran dari musuh alami dapat membantu manusia dalam pengendalian hama dan juga menjaga kestabilan jaring-jaring makanan pada suatu ekosistem pertanian (Pradhana et al, 2014).

Hasil studi kunjungan harian Arthropoda pada tanaman Ageratum conyzoides dan Acalipa australis di area pertanian dusun Ketanon kecamatan Diwek digunakan sebagai bahan pengembangan e-katalog Arthropoda (Gambar 3). 

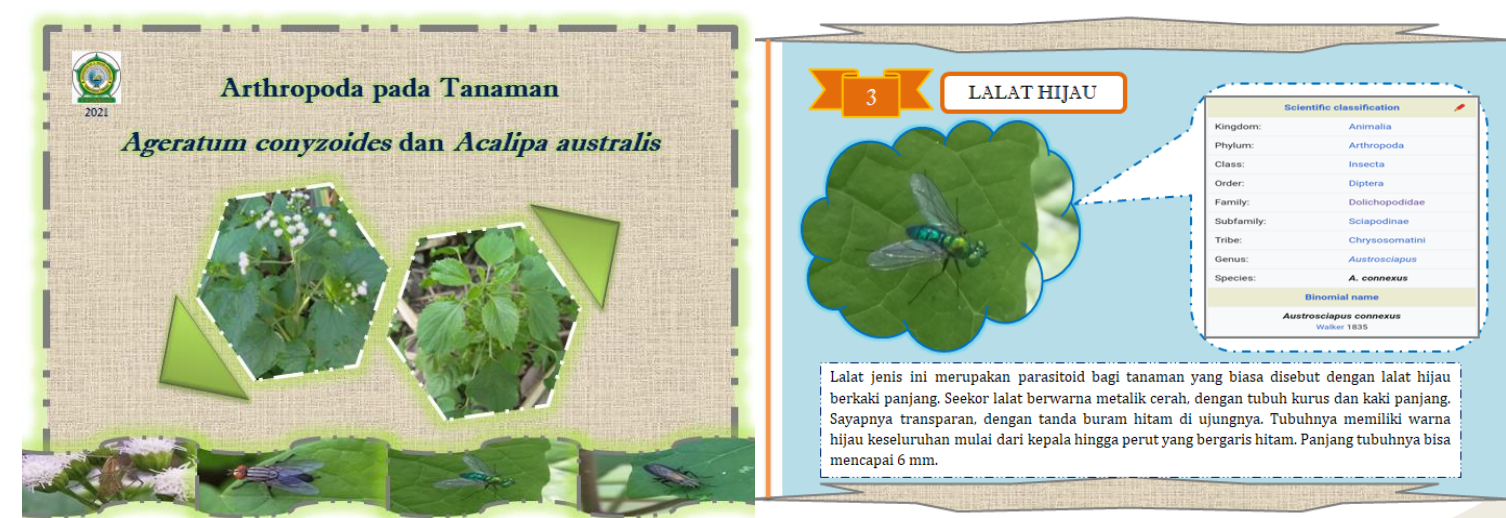

Gambar 3. Sebagian Contoh Hasil Pembuatan Cover dan Isi Bahan
Pengembangan E-katalog Arthropoda sebagai Hasil Penelitian

Hasil bahan pengembangan e-katalog Arthropoda tersebut disusun dalam bentuk e-katalog Arthropoda sederhana sehingga dapat digunakan sebagai bahan pengembangan e-katalog Arthropoda lebih lanjut yang sempurna dan menarik. Jadi, hasil dari pengamatan penelitian ini digunakan sebagai bahan pengembangan e-katalog Arthropoda dengan sebagian contoh cover dan isi bahan pengembangan e-katalog Arthropoda serta dapat menambah pengetahuan atau wawasan tentang keanekaragaman jenis Arthropoda pada tanaman Ageratum conyzoides dan Acalipa australis. Hasil penelitian dijadikan bahan pengembangan e-katalog Arthropoda sederhana berukuran A5 dengan tampilan isi dan latar belakang menarik dan rapi seperti menggunakan berbagai warna untuk latar belakangnya dan juga model bentuk dalam setiap isi halaman bahan pengembangan e-katalog Arthropoda yang dibuat sederhana.

Bahan pengembangan e-katalog Arthropoda yang sederhana ini dibuat untuk memudahkan pendidik dalam pengembangan e-katalog Arthropoda selanjutnya dengan memadukan materi dalam proses pembelajaran sehingga dapat menumbuhkan motivasi belajar peserta didik dan akan lebih mudah dipahami oleh peserta didik yang akan memungkinkan untuk menguasai tujuan pembelajaran dengan lebih baik. Seperti yang telah dijelaskan oleh Sudjana dan Rivai dalam Azhar Arsyad (2011) bahwa "manfaat media pembelajaran dalam proses belajar yaitu pembelajaran akan lebih menarik perhatian peserta didik sehingga dapat menumbuhkan motivasi belajar". Maka, selain untuk menambah motivasi peserta didik, bahan pengembangan e-katalog Arthropoda tersebut pun dapat pula digunakan oleh seorang petani.

Para petani dapat menggunakan hasil bahan pengembangan e-katalog Arthropoda ini untuk menambah wawasan tentang jenis Arthropoda pada tanaman Ageratum conyzoides dan Acalipa australis sebagai pengantisipasi penggunaan pestisida dalam penghematan biaya untuk pengelolaan hama. Selain itu, para petani dapat mengetahui betapa pentingnya adanya tanaman refugia di area pertanian sebagai penanggulangan hama sehingga pendapatan ekonomi dapat bertambah atau lebih maksimal.

\section{KESIMPULAN DAN SARAN}

\section{Kesimpulan}

Hasil penelitian ini dapat disimpulkan bahwa jenis Arthropoda yang ditemukan berkunjung di tanaman Ageratum conyoides dan Acalipa australis berjumlah 11 famili dengan 12 spesies. Frekuensi kunjungan harian Arthropoda tertinggi pada tanaman Ageratum conyzoides adalah famili Agromyzidae (hama), sedangkan pada tanaman 
Acalipa australis adalah famili Formicidae (musuh alami). Distribusi temporal kunjungan harian Arthropoda pada masing-masing tanaman menunjukkan bahwa waktu kunjungan Arthropoda setiap individu/jam adalah berbeda, dengan kata lain setiap individu mempunyai waktu kegiatan/kebutuhan berkunjung masing-masing. Bahan pengembangan e-katalog diperoleh dari hasil data pengamatan studi kunjungan harian Arthropoda pada tanaman Ageratum conyzoides dan Acalipa australis di area pertanian dusun Ketanon kecamatan Diwek selama 3 kali ulangan pada masing-masing tanaman dapat disusun dalam bentuk bahan pengembangan e-katalog Arthropoda yang sederhana.

\section{Saran}

Dengan adanya hasil penelitian ini, diharapkan dapat memberikan informasi bagi semua pihak bahwa tanaman refugia dapat digunakan sebagai mikrohabitat Arthropoda untuk mengurangi penggunaan insektisida sehingga akan menjadi ramah lingkungan. Diharapkan adanya penelitian lebih lanjut mengenai kunjungan harian Artropoda terhadap jenis serangga dan tanaman refugia lainnya. Dan juga disarankan pada penelitian berikutnya untuk lebih maksimal dan lebih berhati-hati dalam hal pengambilan gambar hewan arthropoda pada tanaman refugia tersebut.

\section{DAFTAR RUJUKAN}

Azhar Arsyad. (2011). Media Pembelajaran. Jakarta: PT Raja Grafindo Persada.

Alrazik, M. U., Jahidin, \& Damhuri. (2017). Keanekaragaman Serangga (Insecta) Subkelas Pterygota di Hutan Nanga-nanga Papalia. J. Ampibi. 2(1), 1-10.

Belchior, Ceres., Del-Claro, Kleber., \& Oliveira, Paulo S. (2012). Seasonal patterns in the foraging ecology of the harvester ant Pogonomyrmex naegelii (Formicidae, Myrmicinae) in a Neotropical savanna: daily rhythms, shifts in granivory and carnivory, and home range. Arthropod-Plant Interactions, 6:571-582. DOI $10.1007 / \mathrm{s} 11829-012-9208-1$

Frei, G and Manhart, C. (1992). Nutzlinge und Schadlinge an Kunstlich Angelegten Ackerkrauststerifen in Getreidefeldern, Verlag Paul Haupt Bern. Stuttgart. Wien, Germany.

Handayani, Sri. (2018). Pengembangan Media Visual Berbasis Katalog pada Mata Pelajaran Fiqh Kelas VI di MI Darul Ma'arif Kecamatan Natar Kabupaten Lampung Selatan (Skripsi tidak diterbitkan), Universitas Islam Negeri Raden Intan, Lampung.

Indriati, G., \& Soesanthy, F. (2015). Serangga Pengisap Pucuk Teh: Empoasca vitis (Homoptera: Cicadellidae) dan Tungau (Acarina). SIRINOV. 3(1), 39-48.

Keppel, G., K.P. Van Niel., G.W. Wardell-Johnson., C.J. Yates., M.Byrne., L. Mucina., A.G.T. Schut., S.D. Hopper., dan S.E. Franklin. (2012). Refugia: Identifying and understanding safe havens for biodiversity under climate change. Global Ecology and Biogeography, 21 (4). doi:10.1111/j.14668238.2011.00686.x. 
Logan, J. David., Wolesensky, J. David., \& Joern, Anthony. (2006). Temperaturedependent phenology and predation in arthropod systems. Ecological Modelling, 471-482. doi:10.1016/j.ecolmodel.2006.02.034.

Lumowa, Sonja V.V. (2011). Efektivitas Ekstrak Babadotan (Ageratum conyzoides L.) Terhadap Tingkat Kematian Larva Spodoptera litura F. Eugenia. 17(3), 186191.

Pebrianti, H. D., Maryana, N., Winasa I. W. (2016). Keanekaragaman parasitoid dan artropoda predator pada pertanaman kelapa sawit dan padi sawah di Cindali, Kabupaten Bogor. Jurnal HPT Tropika. 16(2): 138-146.

Pradhana R., Iman A., Mudjiono G., \& Karindah S. (2014). Keanekaragaman serangga dan laba-laba pada pertanaman padi organik dan konvensional. Jurnal HPT. 2(2): 58-66.

Purwanti, Dewi. (2011). Prilaku Serangga. Jatinangor: Jurusan Biologi Universitas Padjadjaran.

Raimundo, Rafael L. G., Freitas, Andre V. L., \& Oliveira, Paulo S. (2009). Seasonal Patterns in Activity Rhythm and Foraging Ecology in the Neotropical ForestDwelling Ant, Odontomachus chelifer (Formicidae: Ponerinae). Ann. Entomol. Soc. Am. 102(6): 1151-1157.

Sumarmiyati., Handayani, Fitri., \& Sundari. (2019). Keragaman serangga pada pertanaman padi sawah di Kabupaten Kutai Kartanegara, Kalimantan Timur. PROS SEM NAS MASY BIODIV INDON. 5(2), 217-221.

Turista, Dora D.R., Rohman, F., \& Yanuwiadi, B. (2011). Studi Kunjungan Harian Arthropoda pada Tumbuhan Liar Centella asiatica L. dan Synedrlla nodiflora ( L) di Area Kebun Teh Wonosari Singosari Kabupaten Malang (Skripsi tidak diterbitkan), FMIPA Universitas Negeri Malang \& FMIPA Universitas Brawijaya, Malang.

Wulandari, Anggun. (2016). Distribusi Temporal Arthropoda pada Tumbuhan Liar Borreria repens DC. dan Setaria sp. di Area Kebun Teh Wonosari Singosari Kabupaten Malang. Jurnal Pendidikan Biologi dan Sains (PENBIOS). 1(2), 2230 .

Zaironi, Achmad. (2015, November). Hama Penggorok Daun (Liriomyza huidobrensis) pada Tanaman Kedelai. Time To Go West. Retrieved from http://zaironi.web.unej.ac.id/2015/11/17/hama-penggorok-daun-liriomyzahuidobrensis-pada-tanaman-kedelai/ 